\title{
STRUCTURAL COMPARISON OF INTELLIGENCE OF POLISH AND AMERICAN CHILDRENS OF MIDCHILDHOOD
}

\author{
Bogdan Pietrulewicz \\ Doctor of Sciences in Psychology, Professor, Full professor of \\ the Department of Health Psychology \\ Medical University of Gdansk \\ 15, Tuwima Str., Gdańsk, Poland, 80-210 \\ bogdan.pietrulewicz@gum.edu.pl, https://orcid.org/0000-0003-0229-0382
}

\author{
Larysa Zhuravlova \\ Doctor of Sciences in Psychology, Professor, Head of \\ the Department of Developmental Psychology and Counseling \\ Zhytomyr Ivan Franko State University \\ 40, Velyka Berdychivska Str., Zhytomyr, Ukraine, 10008 \\ 1pz2008@ukr.net, https://orcid.org/0000-0003-4020-7279
}

\begin{abstract}
The present study is devoted to the examination of the factor structure of intelligence measured with WISC and WISC-R derived from the testing of the sample of Polish children. The differences in the structure of intelligence that was measured with WISC and WISC-R (developed by Pietrulewicz) were investigated for a group of 30 Polish fourth-grade students (mean age 10.6). Consistent with the results of a number of other investigations, the results of this study demonstrate the considerable factorial similarity of two scales derived through the use of WISC and WISC-R and these results appear to be consistent with the results of American studies that indicate the superiority of the two-factor solution with non-Anglo-American children. Consistent with American findings, the WISC Verbal, Performance, and Full Scale IQs were higher than those on the WISC-R. On both measures, structural results favor for two-factor solution, which approximates Wechsler's Verbal and Performance scales. A third factor, failed to simulate Freedom from Distractibility, accounted for approximately $10 \%$ of the explained variance. On this factor, Coding was heavily weighted, but Arithmetic and Digit Span loadings ranged from modest to negative. Results provide support for the application of the Wechsler intelligence tests for children in cross-cultural settings and for interpreting the third factor according to the dynamics of specific cultures. Today WISC-R continue to be applied still in Poland for diagnostic and research purposes. Despite limitations of the present study which include the small sample size and the restriction of demographic information to rural-urban differences the results of the present study indicate that replicative studies may clarify further the characteristics of the third factor with varying populations and cultures, while still generating hypotheses with regard to formulations for enhancing learning opportunities for individual children irrespective of their ethnicity or ecological backgrounds.
\end{abstract}

Keywords: primary school age, children's intelligence, structure of intelligence, intelligence tests, cross-cultural research WISC, WISC-R. 


\section{Introduction}

The use of psychological and educational tests with culturally different children has been challenged since the initiation of the Larry P. vs. Riles (1972) litigation in the early 1970s. In that litigation, Judge Robert Peckham issued an injunction against the use of IQ tests in appraising placement considerations for Black children with respect to classes for the educationally mentally retarded. This reflects this conclusion, based on expert testimony, that conventional IQ tests do not measure adequately the intellectual functioning, or the future school performance, of minority children. Judge Peckham therefore forbade the state to employ IQ tests for placement of Black children into EMR classes without prior court approval and required that California's EMR classes reflect the Black statistics of the state. In 1984, Judge Peckham's decision was upheld by an appellate court (Snyderman \& Rothman, 1986).

Stimulated by the educational and equity of Larry P., researchers have examined extensively validity and reliability questions that concern IQ tests. In general, and with respect to the Wechsler scales, a number of investigations have failed to demonstrate substantial differences associated with ecosystem, ethnicity and social class on such topics as test reliability (Sandoval, 1979), the pattern of item difficulties (Sandoval, Zimmerman \& Woo-Sam, 1983), and age-raw score correlation across groups (Reynolds, 1980).

Various investigators also have employed factor analysis in order to identify the structure of human intelligence and to appraise the predictive value of Wechsler factor scores for diverse populations (Bernier \& Pietrulewicz, 2010). For example, most researchers assume that similarities of factors across cultures and ethnicity would be an indicator that a test is culturally fair. Thus Hilard (1979) has stated that "If the IQ test is valid and reliable test of innate abilities or abilities, then the factors which emerge on a given test are the same from one population to another" (Hilard, 1979: 53). Judged by this criterion, the WISC-R appears to be essentially unbiased: Factor analyses invariably attribute most of the test's variance to two factors, which provide reasonable approximations of Wechsler's Verbal and Performance scales (Hill, Reddon \& Jackson, 1985). However, some debate persists with regard to the third factor, frequently labeled Freedom from Distractibility (FFD), which a number researchers consider to heavily weighted in Arithmetic, Digit Span, and Coding (Sattler, 1982: 154-156).

Kaufman's (Kaufman, 1975) principal factor analysis of the WISC-R standardization has served as the initial basis for assuming the viability of the third factor. While Kaufman proposed three-factor solution as a most appropriate, his data revealed that three factors with eigenvalues that exceeded one emerged for only 5 of the test's 11 age levels. Since then, other studies have reported mixed results concerning generalizability of the three-factor approach (Carlson, Reynolds \& Gutkin, 1983; Gutkin \& Reynolds, 1980; Hill et al., 1985; Silverstein, 1977). Some research indicates that empirical support for the three-factor approach may be stronger with Anglo-American than with minority American or West European youth.

Reschly (Reschly, 1978) concluded that Anglos clearly fit the three-factor solution, but that this appeared not to be case with American minority youth. Chicano subjects were described acceptably by either a two or three-factor solution; Black and Native American subjects were described best by a two-factor solution. Sandoval (Sandoval, 1982) obtained a WISC-R factor structure for groups of Anglo, Black, and Chicano children and reported factorial structures highly similar across groups. Nonetheless, a three-factor solution appeared only for the Anglos and not for the minority groups. From this, he concluded that ethnic differences lacked 
psychological significance because the third factor explained only $8 \%$ of the variance, and inclusion or exclusion of the third factor appeared not to change factor profiles fundamentally.

The researchers of the present paper are aware only one published study of WISC-R factor analysis with a European sample. This inquiry (Kubinger, Formann \& Schubert, 1980) reported that the scores of German students produced two factors, similar to Verbal Comprehension (VC) and Perceptual Organization (PO). The present study examined the factor structure of WISC and WISC-R derived from the testing of Polish students.

The aim of the presented research is to reveal the factor structure of the intelligence of non-Anglo-American children measured with WISC and WISC-R. Tasks of the research: 1) to carry out a theoretical analysis of the existing researches devoted to the factor structure of children's intelligence; 2) to organize and conduct the research the factor structure of intelligence measured with WISC and WISC-R derived from the testing of the sample of Polish children; 3 ) to conduct a comparative analysis of the factor structure of the intelligence of non-AngloAmerican and Anglo-American children measured with WISC and WISC-R.

\section{Research methods}

The original pool of subjects consisted of all 87 children who were attending fourth grade at Elementary School № 119, Warsaw. In order to screen out gifted or retarded children, the Short Scale of Intelligence (Choynowski, 1980) was administered to all 87 children, and 7 were eliminated because they scored at or above the top or bottom $5 \%$ of the test. One further screening measure was employed in an effort to assure a nonclinical and typical sampling of Polish subjects. All fourth-grade teachers in this school were interviewed and, consequently 4 children who had been provided special programing (behavioral disorders and learning disabilities) also were dropped from the pool of eligible subjects. Each of the remaining 76 potential subjects was assigned a number, and 30 subjects were selected randomly. Of these, 14 were girls and 16 boys; the mean CA was 10.6.

All subjects were tested individually in a small private room of elementary schoolboy four graduate students of the Faculty of Psychology, University of Warsaw. Each examiner had established requisite testing competences on the Polish adaptation of the WISC and WISC-R as developed by Pietrulewicz (Pietrulewicz, 1981). Examiners were assigned randomly to subjects, and no examiner tested the same subject on both scales.

Data analysis employed the Varimax principal factor method. Subjects' scores were rotated orthogonally, and factor analyses were extracted.

\section{Results and discussion}

Table 1 summarizes the means and standard deviations for both scales. In general subjects' scores are somewhat higher than those reported for American subjects. On both scales, especially high scores appear on Vocabulary, low scores on Digit Span. Consistent with other reported studies, WISC Verbal, Performance, and Full Scale IQs are somewhat higher than those on the WISC-R.

Results on the WISC Varimax solution are summarized in table 2 and 3. These tables show that the first two factors reasonably approximate Wechsler's Verbal and Performance scales and together account for 54\% of the explained variance; it seems accurate to describe the two-factor solution by the terms VC and PO. 
Mean Scaled Scores and Standard Deviations on the WISC and WISC-R

\begin{tabular}{|c|c|c|c|c|}
\hline \multirow{2}{*}{ SD } & \multicolumn{2}{|c|}{ WISC } & \multicolumn{2}{c|}{ WISC-R } \\
\cline { 2 - 5 } & M & SD & M & SD \\
\hline Information & 12.4 & 2.8 & 12.3 & 1.7 \\
\hline Comprehension & 12.3 & 2.5 & 10.5 & 1.8 \\
\hline Arithmetic & 11.8 & 3.1 & 11.2 & 2.5 \\
\hline Similarities & 13.2 & 2.6 & 11.4 & 3.1 \\
\hline Vocabulary & 16.1 & 3.3 & 13.9 & 2.8 \\
\hline Digit Span & 8.5 & 1.5 & 8.7 & 1.9 \\
\hline Picture Completion & 12 & 2.3 & 11.5 & 2.3 \\
\hline Picture Arrangement & 9.4 & 2.5 & 10.5 & 2.5 \\
\hline Block Design & 13.2 & 3.6 & 12.3 & 3.3 \\
\hline Object Assembly & 10.7 & 3.8 & 12.0 & 3.7 \\
\hline Coding & 11.3 & 3.5 & 9.1 & 3.2 \\
\hline Mazes & 10 & 2.6 & 11.8 & 3.7 \\
\hline Verbal Scale & 114.8 & 11.5 & 107.8 & 10 \\
\hline Performance Scale & 107.8 & 15.7 & 109.2 & 15.4 \\
\hline Full Scale & 112.3 & 12.4 & 109.2 & 10.9 \\
\hline
\end{tabular}

However, the third factor is difficult to explain. It accounts for approximately $10 \%$ of the explained variance and is loaded heavily on Coding and, to a lesser extent on Picture Arrangement, Mazes, and Picture Completion. Essentially, the third factor is associated with Performance Scale subtests. Only moderate and negative loadings appear on the two subtests associated with FFD, Digit Span and Arithmetic, respectively.

Table 2

Varimax solutions of the WISC

\begin{tabular}{|c|c|c|c|}
\hline & $\mathbf{1}$ & $\mathbf{2}$ & $\mathbf{3}$ \\
\hline Information & 0.9 & 0.13 & 0.07 \\
\hline Comprehension & 0.68 & 0.2 & 0.1 \\
\hline Arithmetic & 0.36 & 0.66 & -0.07 \\
\hline Similarities & 0.77 & 0.05 & 0.09 \\
\hline Vocabulary & 0.83 & -0.05 & 0.16 \\
\hline Digit Span & 0.47 & -0.64 & 0.31 \\
\hline Picture Completion & 0.4 & 0.47 & 0.42 \\
\hline Picture Arrangement & 0.24 & 0.26 & 0.58 \\
\hline Block Design & 0.14 & 0.83 & 0.23 \\
\hline Object Assembly & 0.07 & 0.75 & 0.31 \\
\hline Coding & 0.12 & -0.01 & 0.88 \\
\hline Mazes & -0.09 & 0.52 & 0.48 \\
\hline
\end{tabular}


Table 3

Characteristics of the Three-factor Solution on the WISC

\begin{tabular}{|c|c|c|c|}
\hline & Coefficient Lambda & Percent of explained variance & $\begin{array}{c}\text { Percent of cumulative explained } \\
\text { variance }\end{array}$ \\
\hline 1 & 4.13 & 34.4 & 13.4 \\
\hline 2 & 2.37 & 19.71 & 54.11 \\
\hline 3 & 1.2 & 10.03 & 64.14 \\
\hline
\end{tabular}

Factor results on the WISC-R appear in Table 4 and 5. Again, the VC and PO factors appear and account for over half (53\%) of the explained variance. As was the case with the WISC, the third factor accounts for about $10 \%$ of the explained variance and is not easy to interpret. Similar to WISC observations, composition of the third factor is affected significantly by a high positive loading on Coding; the only other significant subtest weightings occur with respect to Arithmetic and Information.

Table 4

Varimax solutions of the WISC-R

\begin{tabular}{|c|c|c|c|}
\hline & $\mathbf{1}$ & $\mathbf{2}$ & $\mathbf{3}$ \\
\hline Information & 0.73 & -0.05 & -0.48 \\
\hline Comprehension & 0.74 & 0.13 & -0.02 \\
\hline Arithmetic & 0.29 & 0.03 & -0.8 \\
\hline Similarities & 0.8 & 0.13 & -0.08 \\
\hline Vocabulary & 0.72 & 0.04 & -0.23 \\
\hline Digit Span & 0,57 & -0.4 & 0.02 \\
\hline Picture Completion & 0.52 & 0.51 & 0.05 \\
\hline Picture Arrangement & 0.6 & 0.35 & 0.05 \\
\hline Block Design & 0.07 & 0.87 & -0.18 \\
\hline Object Assembly & 0.2 & 0.86 & 0.18 \\
\hline Coding & 0.52 & 0.12 & 0.64 \\
\hline Mazes & -0.02 & 0.79 & 0.05 \\
\hline
\end{tabular}

Table 5

Characteristics of the Three-factor Solution on the WISC-R

\begin{tabular}{|c|c|c|c|}
\hline & Coefficient Lambda & $\begin{array}{c}\text { Percent of explained } \\
\text { variance }\end{array}$ & $\begin{array}{c}\text { Percent of cumulative } \\
\text { explained variance }\end{array}$ \\
\hline 1 & 4.03 & 33.5 & 33.5 \\
\hline 2 & 2.37 & 19.73 & 53.28 \\
\hline 3 & 1.33 & 11.08 & 64.36 \\
\hline
\end{tabular}

The findings of this investigation reveal substantial congruence with regard to the factor structures, and the extent of variability associated with the specific factors, of the WISC and WISC-R. This finding is consistent with American studies that have found strong similarities in the characteristics of the two scales, which perhaps is not surprising because the scales draw upon the same organization, and $84 \%$ of WISC items were retained in the WISC-R (Wechsler, 
1974). Also consistent with American findings is the observation that the Polish subjects secured higher Verbal, Performance, and Full Scale IQs on the WISC than on the WISC-R (Sattler, 1982: 151). The mean IQ for the Polish children on the Performance Scale was slightly higher than on the WISC despite higher WISC-R scores on two subtests, Picture Arrangement and Object Assembly, which are likely to produce elevated scores on retesting.

On both scales the two-factor solution emerges and provides an approximation of the Wechsler Verbal and Performance scales; this is consistent with virtually all WISC and WISC-R factor analyses (Hill et al., 1985). However, the psychological significance of the third factor is puzzling. On both scales only Coding loads heavily on this factor; the other two subtests normally associated with the third factor load only modestly (Digit Span) or negatively (Arithmetic).

Because results from this study indicate not only the quasi-uniqueness but also the psychological significance of the third factor, which on both scales accounted for approximately $10 \%$ of the explained variance, the theoretical rationale of Coding deserves specific consideration. In some respects, Coding is maverick. The poorest measure of $g$, it demonstrates subtest specificity along the entire CA spectrum measured by both scales (Sattler, 1982: 186). Further, Evans and Stroebel (Stroebel, 1986) have noted that children designated as learning disabled often have unusual difficulty on this measure, which appears dependent on memory, writing, speed and paired associate learning rate. Sattler (Sattler, 1982) notes that although success in Coding requires that children comprehend the task, skill with paper and pencil is also significant. Further investigation may reveal factors within the Polish culture, such as availability of paper and pencil for visual-spatial activities at home and school, that may account for the emergence of Coding as an important and relatively independent IQ component.

The results also suggest that ongoing efforts are warranted to clarify the relationship between the third factor and cultural specificity. In one of the few published studies that employed factor analysis on the WISC-R with West Europeans, Digit Span scores were relatively high and operated with approximately the same degree of independence as did Coding with the Polish subjects of this study (Kubinger et al., 1980). The researchers are aware of very different environmental circumstances in Eastern and Western Europe and hypothesize that the low Digit Span scores of the Polish subjects may reveal the impact of cultural factors, especially because depressed scores on this measure often are associated with excessive anxiety (Sattler, 1982: 178).

Limitations of the present study include the small sample size and the restriction of demographic information to rural-urban differences; also and in retrospect, it would have been advisable to administer the scales immediately in counterbalanced order.

\section{Conclusions}

Consistent with a number of other investigations, result of this study demonstrate considerable factorial similarity of two scales, provide evidence consistent with American studies that indicate the superiority of the two-factor solution with non-Anglo-American children, and suggest that replicative studies may clarify further the characteristics of the third factor with varying populations and cultures, while still generating hypotheses with regard to formulations for enhancing learning opportunities for individual children irrespective of their 
ethnicity or ecological backgrounds. The replicative studies devoted to clarification of the characteristics of the third factor are needed.

These future researches should be done with varying populations and cultures of children with respect to their ethnicity and ecological background.

\section{References}

1.Bernier, J.J., \& Pietrulewicz, B. (2010). La psychometrie traite de mesure appliquee. MontrealParis-Casablanca : Gaetan Morin Editeur.

2.Carlson, L., Reynolds, C.R., \& Gutkin, T.B. (1983). Consistency of the factorial validity of the WISC-R for upper and lower SES groups. Journal of School Psychology, 21, 319-326.

3.Choynowski, M. (1980). Podręcznik do Krótkiej Skali Inteligencji. In Testy psychologiczne w poradnictwie wychowawczo-zawodowym. Warszawa : PWN.

4.Evans,J., \& Stroebel, S. (1986). A standardization of two measures that supplement WISC-R Coding subtest results. Journal of Clinical Psychology, 42, 654-657.

5.Gutkin, T.B., \& Reynolds, C.R. (1980). Factorial similarity of the WISC-R for Anglos and Chicanos referred for psychological services. Journal of School Psychology, 18, 34-39.

6.Hill, T.D., Reddon, J.R., \& Jackson, D.N. (1985). The factor structure of the Wechsler Scales: A brief review. Clinical Psychology Review, 5, 287-306.

7.Hillard, G.I. (1979). Standardization and cultural bias as impediments to the scientific study and validation of "intelligence". Journal of Research and Development in Education, 12, 4758.

8.Kaufman, A.S. (1975). Factor analysis of the WISC-R at 11 age levels between 6 and 16 years. Journal of Consulting and Clinical Psychology, 43, 135-147.

9.Kubinger, K.D., Formann, A.K., \& Schubert, M. (1980). WISC-R faktor analysis: Untersuchung Zwei und Drei Faktor Ergebnisse. Zeitschrift fur Differentielle und Diagnostische Psychologie. 1, 117-126.

10. Larry P. vs. Riles, 343 F. Supp.1306 (N.D. Cal. 1972) aff' d502 F. 2d. 963 (9 ${ }^{\text {th }}$ Cir. 1974) (Preliminary injunction): No. C-71-2270 RFP slip op. (Oct. 16, 1979) (decision on merits).

11. Pietrulewicz, B. (1981). Polska adaptacja Wechsler Intelligence Scale for Children-Revised. Zagadnienia Wychowawcze a Zdrowie Psychiczne, 7, 3-6.

12. Reschly, D.J. (1978). WISC-R factor structures among Anglos, Blacks, Chicanos and Native American Papagos. Journal of Consulting and Clinical Psychology, 46, 417-422.

13. Reynolds, C. (1980). Differential construct validity of intelligence as popularly measured: Correlations of age with raw scores on the WISC-R for Blacks, Whites, males and females. Intelligence, 4, 374-379.

14. Sandoval, J. (1979). The WISC-R and internal evidence of test bias with minority groups. Journal of Consulting and Clinical Psychology, 47, 919-927.

15. Sandoval, J. (1982). The WISC-R factorial validity for minority groups and Spearman's hypothesis. Journal of School Psychology, 20, 198-204.

16. Sandoval, J., Zimmerman, I., \& Woo-Sam, J. (1983). Cultural differences on the WISC-R verbal items. Journal of School Psychology, 21, 198-204.

17. Sattler, J. M. (2018). Assessment of children's intelligence and special abilities, sixth edition. Boston : Jerome Sattler Editor.

18. Silverstein, A.B. (1977). Alternative factor analytic solutions for the Wechsler Intelligence Scale for Children-Revised. Educational and Psychological Measurement, 37, 12-24.

19. Snyderman, M., \& Rothman, S. (1986). Science, politics and the IQ controversy. Public Interest, 83, 79-97.

20. Wechsler, D. (1974). Manual for the Wechsler Intelligence Scale for Children-Revised. New York : Psychological Corporation. 


\section{СТРУКТУРНЕ ПОРІВНЯННЯ ІНТЕЛЕКТУ ПОЛЬСЬКИХ ТА АМЕРИКАНСЬКИХ ДІТЕЙ МОЛОДШОГО ШКІЛЬНОГО ВІКУ \\ Богдан Петрулевич \\ доктор психологічних наук, професор, професор кафедри психології здоров’я}

Гданський медичний університет

80-210, Польща, м. Гданськ, вул. Тувіма, 15

bogdan.pietrulewicz@gum.edu.pl,https://orcid.org/0000-0003-0229-0382

Лариса Журавльова

доктор психологічних наук, професор,

завідувач кафедри психології розвитку та консультування

Житомирський державний університет імені Івана Франка

10008, Україна, м. Житомир, вул. Велика Бердичівська, 40

1pz2008@,ukr.net, https://orcid.org/0000-0003-4020-7279

\section{Анотація}

Дослідження присвячено вивченню факторної структури інтелекту, діагностованої за допомогою WISC та WISC-R (шкала інтелекту Векслера для дітей), за результатами тестування вибірки польських дітей. Відмінності в структурі інтелекту, які вивчалися за допомогою методик WISC i WISC-R (Б. Петрулевич), було досліджено в групі з 30 польських учнів четвертого класу (середній вік - 10,6 років). Результати проведеного дослідження узгоджуються з результатами американських досліджень у цьому напрямку та демонструють значну факторну схожість двох шкал, отриманих за допомогою WISC i WISC-R, що може свідчити про перевагу двофакторного рішення при аналізі структури інтелекту не англо-американських дітей. Отримані показники діагностики структури інтелекту відповідають таким результатам американських досліджень: VIQ, PIQ та FSIQ за WISC були вищими, порівняно з показниками WISC-R. В обох випадках структурні показники свідчать на користь двофакторного рішення, яке близьке до VIQ та PIQ шкал Векслера. За допомогою третього фактора, який описує майже $10 \%$ дисперсії, не вдалося змоделювати шкалу «Свобода від відволікання». Результати за цим фактором виявилися досить вагомими, проте навантаження арифметичних і цифрових діапазонів коливалися у проміжку від незначних додатніх до від'ємних значень. Результати свідчать про виправданість застосування тестів інтелекту Векслера для дітей у міжкультурних умовах і про необхідність інтерпретації третього фактора, згідно з динамікою конкретних культур. На сьогодні WISC-R продовжують застосовуватися у Польщі для діагностичних i дослідницьких цілей. Незважаючи на обмежуючі особливості проведеного дослідження, а саме: невеликий розмір вибірки й обмеження демографічної інформації про групи сільського і міського населення, отримані результати засвідчують, що реплікативні дослідження можуть додатково уточнити характеристики третього фактора в демографічному й культурному зрізах $\mathrm{i}$ сприятимуть формулюванню гіпотез про можливість підвищення ефективності навчання окремих дітей, незалежно від їх етнічної належності та екологічного походження.

Ключові слова: молодший шкільний вік, дитячий інтелект, структура інтелекту, тести інтелекту, крос-культурні дослідження, WISC, WISC-R. 